УДК 314.151.3-054.73(=511.141)(497.5)“1941/1946“(093.2)

94:323.15(=511.141)(497.5)“1941/1945“

Dr Marica KARAKAŠ OBRADOV

Hrvatski institut za povijest, Zagreb,

Republika Hrvatska

\title{
MIGRACIJE MAĐARSKOG STANOVNIŠTVA NA HRVATSKOM PODRUČJU TIJEKOM DRUGOG SVJETSKOG RATA I NEPOSREDNO POSLIJE
}

\begin{abstract}
APSTRAKT: Članak na temelju arhivskog gradiva i literature obrađuje mađarsko-hrvatske pregovore o razmjeni stanovništva, te pitanje razgraničenja koje je bitno usmjeravalo migracije stanovništva. U radu su ponajprije obrađena preseljavanja, odnosno evakuacije mađarskog stanovništva zbog ratnih opasnosti, posebice napada partizana, s područja NDH u sigurnija područja, pretežno u Bačku te iseljavanje i protjerivanje $s$ područja pod partizanskom vlašću tijekom rata koje će se nastaviti i u poraću.
\end{abstract}

Ključne riječi: Drugi svjetski rat, „narodna demokaracija“, Nezavisna Država Hrvatska, Hrvatska, Mađari, migracije, iseljavanja, preseljavanja/evakuacije, izbjeglištvo, protjerivanja

\section{Kratki pregled mađarsko-hrvatskih odnosa tijekom Drugog svjetskog rata}

Mađarska je u travnju 1941. sudjelovala u zaposjedanju Kraljevine Jugoslavije. Mađarski kraljevski namjesnik Miklós Horty, de facto 11. travnja, a de iure 22. travnja 1941, priznao je NDH. Nešto ranije mađarska strana odbila je ponudu Trećeg Reicha da nakon razbijanja Kraljevine Jugoslavije pripoji Hrvatsku. Mađarska se potom posvetila „svetoj dužnosti“ zaštite mađarskog stanovništva u tzv. Južnim krajevima/Délvidék (Bačka, Baranjski trokut, Prekmurje/Prekomurje i Međimurje). To je značilo pripajanje područja koja su izgubili nakon Prvog svjetskog rata, a koja su pripala susjednim državama. Međimurje je imalo neznatno značenje u usporedbi s drugim 
područjima koja su bila u sastavu Kraljevine Jugoslavije, posebice Bačka. Već 14. travnja 1941. postavljeno je pitanje razgraničenja Mađarske i NDH. Mađarska je tražila da joj se ustupi Rijeka kao državna luka, koja u konačnici nije ušla u sastav NDH, a postojao je i plan o ustrojavanju „Mađarskog primorja“ od Rijeke do ušća Zrmanje. Osobito su Mađari bili odlučni da pripoje Međimurje u koje je mađarska vojska ušla već 16. travnja 1941, a što će postati glavni kamen spoticanja u odnosima dviju država. ${ }^{1}$

U svibnju i lipnju 1941. Hrvatski narod povremeno je objavljivao članke o prijateljstvu sa susjednom Mađarskom i izvješćivao o aktivnostima mađarskog poslanika i vojnog atašea u NDH unatoč provođenju mjere uspostavljanja mađarske uprave u Međimurju. ${ }^{2}$ U srpnju 1941. u potpunosti je uvedena mađarska vojna uprava u Međimurju, a u prosincu 1941. mađarski parlament jednostrano je ozakonio pripajanje Međimurja. NDH nije nikada službeno isticala da je sjeverna granica njenog državnog područja utvrđena jer nije bilo obostranog dogovora. Kako su Mađari imali pretenzija i na područja u Slovačkoj i Rumunjskoj javila se ideja o osnivanju Male antante kojim bi se Rumunjska, Slovačka i NDH ,borile za opstanak“ pred ,nagonom osvajačke megalomanije“ i ,psihologije osvajanja“ koju su Mađari pokazivali prema susjedima. No, Mađare je više brinula jurisdikcija zagrebačke biskupije nad Međimurjem od Male antante. Vlasti NDH, odnosno ministar vanjskih poslova Mladen Lorković, uložio je prosvjednu notu mađarskom poslaniku u NDH Ferencu pl. Marosyju, a obaviještene su i vlade zemalja Trojnog pakta, o tome da je Međimurje od ,pamtivijeka naseljeno Hrvatima“, te da je „stoljećima sačinjavalo dio Hrvatske“. Ukoliko bi se Mađari odrekli ,,primitivnih političkih ciljeva“ oko zaposjedanja Međimurja, kako je to Hrvatima sklon poslanik Mađarske u NDH Ferenc Marosy sročio, hrvatska strana bila je spremna prihvatiti Bačke Hrvate. Marosy je smatrao da je Međimurje za

1 Hrvatski državni arhiv (dalje HDA), Zagreb, Ministarstvo vanjskih poslova NDH (dalje MVP NDH), kut. 6, br. 535/1941; Hrvatski narod (Zagreb), 20. travnja 1941, str. 3 i 22. travnja 1941, str. 2; Dinko Šokčević, „Nezavisna Država Hrvatska i Mađarska 1941. godine. Pitanje diplomatskog priznanja“, Međunarodni znanstveni skup. „Jugoistočna Europa 1918.-1995. “/An international Symposium ,, Southern Europe 1918-1995 “(ur. Aleksander Ravlić), Zagreb, 1999, str. 111-112; Ivana Puzak, „Međimurje u Drugom svjetskom ratu iz pera hrvatskih i mađarskih emigranata“, Međimurje u Drugom svjetskom ratu, (ur. Branimir Bunjac), Čakovec, 2007, str. 416; Arpad Hornyák, ,Jugoslavenski teritorijalni zahtjevi prema Mađarskoj i susjednim zemljama i planovi za njihovu primjenu nakon Drugog svjetskog rata“, Časopis za suvremenu povijest (dalje ČSP), god. 42, 1/2010, str. 23-24.

2 Hrvatski narod, 5. svibnja 1941, str. 10, 6. svibnja 1941, str. 7, 16. svibnja 1941, str. 9, 4. lipnja 1941, str. 6 i 24. lipnja 1941, str. 11; Marin Mihanović, „Mađarsko Pitanje u hrvatsko-rumunjskim odnosima od 1941. do 1944. godine: pokušaj obnove Male Antante“, $\check{C} S P$, god. 33, br. 2/2001, str. 326.

3 Hrvatski narod, 11. srpnja 1941, str. 1. i 12. srpnja 1941, str. 1; Ustaša. Viestnik Hrvatskog ustaškog oslobodilačkog pokreta (Zagreb), 19. srpnja 1941, str. 4 i 10; Elemer Hamonnay, „Hrvatska i Mađarska“, Hrvatska misao, sv. 12, Buenos Aires, 1955, str. 22; Hrvoje Matković, 
Mađare „rasno izgubljeno“, te da bi trebali usmjeriti snage na rješavanje pitanja razmijene stanovništva, Bunjevaca i Šokaca, i drugih preseljenja. ${ }^{3}$

Od 25. lipnja do 11. srpnja 1942. hrvatsko-mađarska komisija radila je u Budimpešti na utvrđivanju istočne granice, a pitanje Međimurja nije rješavano te je stalno postojala napetost u odnosima dviju država. ${ }^{4}$

Od 1941. do 1943. Mađarska i NDH sklopile su brojne bilateralne ugovore koji su se većinom odnosili na uređenje poštanskog, telekomunikacijskog, željezničkog, riječnog i pograničnog prometa, reguliranje ribolova na Dunavu i Dravi, no niti jedan se nije odnosio na pitanje granice. Samo se jedan zakon odnosio na odnos država, Mađarske i NDH, prema Hrvatima odnosno Mađarima. Bio je to Zakon o pravnoj pomoći i pravnoj zaštiti u stvarima građanskog i trgovačkog prava. ${ }^{5}$

Tijekom rata Mađari u NDH uglavnom su bili organizirani u dva mađarska udruženja. U Zagrebu je bilo sjedište Mađarske kulturne zajednice (MKZ)/ Horvátországi Magyar Közmúvelödési Közösség koja je isprva djelovala u stanu njenog vođe Sándora Molnara, a glavnu materijalnu podršku dobivali su od Gyule Tokozia, pomađarenog Židova. On je izvršio samoubojstvo u Zagrebu zbog progona Židova, te svoju cjelokupnu imovinu poklonio MKZ-i. Podružnice su djelovale i u drugim gradovima u NDH. ${ }^{6}$

Na području NDH djelovala je i mađarska skupina „Strelastih križeva“/ „Nyilaskereszt“ koji su sebe smatrali glavnim predstavnicima mađarskog stanovništva, a sjedište im je bilo u Osijeku. Sukobljavali su se s predstavnicima MKZ, uključujući i fizičke napade, tako da je MUP NDH u ožujku 1942. izdao uputu svim velikim župama i Redarstvenoj oblasti grada Zagreba da niti jedna od ovih skupina formalno ne predstavlja „,mađarsku narodnu grupu“ jer nemaju potvrđena pravila o svom djelovanju u NDH, te da se prema članovima jednog i drugog udruženja treba ponašati ravnopravno i „onemogućiti“ da se međusobno sukobljavaju dok se to pitanje zakonski ne riješi. ${ }^{7}$

Vlasti NDH nastojale su lavirati između ,zavađenih strana“, MKZ i Strelastih križeva i tako steći prednosti u rješavanju pitanja zaposjedanja i pripojenja Međimurja i protjerivanja Hrvata s toga područja. U travnju 1942. vlasti

Suvremena politička povijest Hrvatske, Zagreb, 1999, str. 172; Tomislav Jonjić, Hrvatska vanjska politika 1939.-1942., Zagreb, 2000, str. 559; M. Mihanović, „Mađarsko Pitanje u hrvatsko - rumunjskim odnosima od 1941. do 1944. godine: pokušaj obnove Male Antante“, str. 337; Enikő A Sajti, Hungarian Minority in the Vojvodina 1918-1947, Boulder/Colorado, 2003, str. 272-278; Enike A. Šajti, Mađari u Vojvodini 1918-1947, Novi Sad, 2010, str. 168-171.

4 HDA, MVP NDH, kut. 6, br. 588/1941; Aleksandar Kasaš, Mađari u Vojvodini 1941-1946, Novi Sad, 1996, str. 124; T. Jonjić, Hrvatska vanjska politika 1939.-1942., str. 563.

5 Međudržavni ugovori 1941, Ministarstvo vanjski poslova NDH, Zagreb, 1941, XXIV-XXV; Međudržavni ugovori 1942, XXI-XXIII, str. 91-92; Međudržavni ugovori 1943, XV-XVII, str. 321.

6 A. Kasaš, Mađari u Vojvodini 1941-1946, str. 125.

7 HDA, MVP NDH, kut. 6, 4708/1941; A. Kasaš, Mađari u Vojvodini 1941-1946, str. 127. 
NDH su zabranile da pripadnici MKZ i Strelastih križeva u javnim nastupima koriste mađarsku zastavu i općenito se predstavljaju kao „posebna grupa“. Podjele dviju mađarskih skupina ubrzo su nadvladane jer je djelovanje „Strelastih križeva" na području NDH zabranjeno krajem 1942, pa samim tim djelovanje i u Mađarskoj. Tijekom 1943. pod njemačkim okriljem ponovno oživljava rad „Strelastih križeva“ koji su sudjelovali u borbi protiv partizana, a Gyula Süto s njemačkom putovnicom prešao je iz Mađarske na područje NDH i obnovio rad na osječkom području. U travnju 1944. MKZ u Osijeku i mjesni „Strelasti križevi“" zaključili su ugovor o suradnji. ${ }^{8}$

Vlasti NDH su u pravilu ocjenjivale držanje Mađara u NDH „mirnim i lojalnim", ali su i dalje bili sumnjičavi prema mađarskim teritorijalnim posezanjima. U ljeto 1942. vlasti NDH su ustvrdile da je nacionalistički pokret zahvatio pripadnike mađarske zajednice koji bježe od vojne obaveze u Mađarsku i zajedno s ,pobunjenicima“ žele srušiti hrvatsku vlast, te da se na području Mađarske ustrojavaju tzv. „slobodne čete“ koje u ,civilnim odjelima“ prelaze na područje NDH izazivajući nerede i diverzije, a namjera im je prijeći u Srijem i „očistiti“ Frušku Goru od „komunista“. Napetost u odnosima pokazao je i skup Mađara u Inđiji koji su u junu 1942. na skupštini svoje čitaonice pozvali prisutne da budu „mirni i strpljivi“ jer će i to područje uskoro postati mađarsko. ${ }^{9}$

Strah vlasti NDH od teritorijalnih posezanja Mađara još je jednom snažno potaknut. Naime, u kolovozu 1944. njemački opunomoćeni general u Zagrebu, Edmund Glaise von Horstenavu predložio je zajedničku mađarsko-hrvatsku vojnu suradnju u borbi protiv partizana, te su Mađari dobili pravo prodrijeti na susjedno državno područje deset kilometara. Hrvatska strana to nije prihvatila s prevelikim odobravanjem jer je postajala bojazan zbog nekih ideja s početka rata da hrvatsko područje bude autonomni dio u sklopu Mađarske. Mađari ponajviše iz straha od širenja „partizanske opasnosti“ na svoje državno područje i sami traže da se mora izbjeći utisak u hrvatskoj javnosti o obnovi ideje o „zemljama krune Svetog Stjepana“. ${ }^{10}$

Uvođenje vojne uprave u Međimurju prekinulo je mogućnost pregovora o većoj razmjeni stanovništva i ubuduće su dvije države tražeći ravnotežu pokušavale urediti položaj svojih manjina izvan matične zemlje. Arbitraža Trećeg Reicha, koju su obje strane tražile, a potom njemački neutralni stav po tom pitanju, potpuno je išao u prilog Mađarima. Hrvatska strana nadala se, ako ne prije onda po završetku rata, da će prema etničkom načelu Međimurje biti pono-

8 HDA, MVP NDH, kut. 6, 4708/1941; E. A Sajti, Hungarian Minority in the Vojvodina 19181947, str. 279; E. A. Šajti, Mađari u Vojvodini 1918-1947, str. 172.

9 A. Kasaš, Mađari u Vojvodini 1941-1946, str. 125 i 126.

10 E. A. Sajti, Hungarian Minority in the Vojvodina 1918-1947, str. 287-288; E. A. Šajti, Mađari u Vojvodini 1918-1947, str. 178-179.

11 HDA, MVP NDH, kut. 6, 535/1941 i 907/1941; Nada Lazić, Baranja 1941-1945, Slavonski Brod, 1979, str. 101, bilj. 42; A. Kasaš, Mađari u Vojvodini 1941-1946, str. 124-125; E. A 
vno hrvatsko. Hrvatska strana stalno je ulagala proteste zbog odnosa prema Hrvatima u Međimurju te „hrvatskom elementu“, Bunjevcima i Šokcima, u Baranji i Bačkoj. ${ }^{11}$

\section{Iseljavanje i evakuacije Mađara tijekom Drugog svjetskog rata na hrvatskom području}

U travnju 1941. mađarska vlada poslala je Aladára Tamása, koji je imao kontakte s Ustaškim pokretom još u vrijeme kada su djelovali u emigraciji, sa zadaćom da ispita njihov stav oko moguće razmjene stanovništva. Poglavnik Ante Pavelić izrazio je odmah spremnost da NDH prihvati Bačke Hrvate koji bi se naselili na mjesto iseljenih i protjeranih Srba. Složio se takođe da se preko hrvatskog područja može obaviti prijelaz Srba s mađarskog područja u Srbiju, ali da NDH neće primiti solunske dobrovoljce na svoje državno područje. Daljnje rasprave o preseljavanju stanovništva nisu mogle teći po planu jer je problem zaposjedanja Međimurja od strane Mađarske opteretio odnose dviju zemalja. Mađarska strana potaknula je „manjinska pitanja“ koja bi se rješavala na bazi uzajamnosti, te su 12. ožujka 1942. predali memorandum MVP NDH s listom pritužbi na položaj hrvatskih Mađara osobito oko djelovanja MKZ, podršku koja se davala djelovanju mađarskih „Strelastih križeva“ u Osijeku i na pitanje škola na mađarskom, uz napomenu da se sve to može odraziti na odnos prema Hrvatima u Mađarskoj. ${ }^{12}$

Na području NDH živjelo je 70.747 Mađara, prema popisu iz 1931, pretežno na području Slavonije, Srijema i Međimurja. ${ }^{13} \mathrm{U}$ prvim ratnim mjesecima, od svibnja do lipnja 1941, na područje Baranje i Bačke mađarske vlasti su naselile 21.380 Mađara iz Bukovine, na posjede iseljenih solunskih dobrovoljaca, pretežno srpskog stanovništva, koje je protjerano u Srbiju i u NDH. ${ }^{14}$

Prve migracije mađarskog stanovništva povezane sa NDH dogodile su se slučajno. Naime, vlasti Trećeg Reicha preseljavajući slovensko stanovništvo

Sajti, Hungarian Minority in the Vojvodina 1918-1947, str. 274; E. A. Šajti, Mađari u Vojvodini 1918-1947, str. 169.

12 E. A. Sajti, Hungarian Minority in the Vojvodina 1918-1947, str. 275-278; E. A. Šajti, Mađari u Vojvodini 1918-1947, str. 168-171.

13 Priručnik o političkoj i sudbenoj podjeli Nezavisne Države Hrvatske (prir. Rafael Landikušić), Zagreb, 1942, str. 13; A. Kasaš, Mađari u Vojvodini 1941-1946, str. 124 navodi da je na području NDH bilo oko 100.000 Mađara od toga 23.000 na području Srijema.

14 Slobodan D. Milošević, Izbeglice i preseljenici na teritoriji okupirane Jugoslavije 1941-1945, Beograd, 1981, str. 79.

15 HDA, Služba državne sigurnosti Republičkog sekretarijata za unutrašnje poslove Socijalističke Republike Hrvatske (dalje SDS RSUP SRH), kut. 69, 014.0.2. Izjava Alojza Colnara, predstavnika Slovenskog Crvenog križa u Zagrebu, str. 20. 
s područja Prekmurja/Prekomurja na područje NDH, zahvatili su i Mađare, oko stotinu ljudi, koji su zabunom dovedeni u Teslić kao Slovenci. Mađarsko poslanstvo u Zagrebu potvrdilo je da su u pitanju Mađari, te su vraćeni u Zagreb. Vlasti su ih potom smjestile u sela u okolici Zagreba jer se oni nisu željeli vratiti u Bosnu, a Nijemci im nisu dopustili povratak u Prekmurje/Prekomurje. ${ }^{15}$

U prosincu 1941. zbog ratnih opasnosti, odnosno napada partizana od kojih ih vlast NDH nije mogla ,zaštiti“" postavljeni su prvi zahtjevi Mađarske za iseljavanje Mađara iz sjeveroistočne Bosne, Brčkog, Bijeljine i iz sela Vučjak kod Prnjavora. U veljači 1942. mađarske vlasti su poduzele prve mjere oko preseljavanja Mađara ,zbog životne opasnosti“" koja prijeti ,razasutoj“ mađarskoj zajednici, te su poslanici Marosy i Lorković dogovorili iseljavanje Mađara. Mađari su se iseljavali iz županjskog kotara iz Gunje, Račinovaca, Soljana i Vrbanje te iz Vučinjaka i Brke iz kotara Brčko, a potom i iz Bijeljine. Zauzvrat su Mađari bili spremni izmijeniti dotadašnju praksu i omogućiti da Hrvati, koji sami odlaze ili su prognani s mađarskog područja, ponesu sobom osobnu imovinu. Mađarska strana je na to bila spremna pristati jer su Mađari iz Gunje bili već spremni sa svojom imovinom za preseljenje, te bi svako odgađanje uznemirilo stanovništvo i izazvalo ,neugodne reakcije“ između Mađara i Hrvata. ${ }^{16}$ Zavod za kolonizaciju NDH bio je nadležan za likvidaciju imanja Mađara koji su se iselili posredovanjem Hrvatsko-mađarskog povjereništva za smještaj Mađara u Zagrebu. Njihova imanja za koja im je isplaćena naknada postala su vlasništvo Zavoda za kolonizaciju. ${ }^{17}$

MVP NDH je 1942. pokrenulo preko MUP-a NDH popisivanje mađarskog stanovništva na području NDH, koje je trebalo provesti velike župe i kotarske vlasti. Ti popisi nisu sačuvani niti je popisivanje bilo dovršeno do ožujka $1943 .{ }^{18}$

Prema dogovoru dviju država, iz travanja 1942, iseljeno je 395 mađarskih obitelji s 1.552 članova, a tijekom 1943. još je iseljeno 1.500 Mađara, uglavnom s područja koja su bila neprekidno zahvaćena ratnim djelovanjem. Većina ih je preseljena u Bačku. Iz Gunje u Stepanovićevo, iz Vučjaka u Veternik, a iz Brčkog u Sirig, te iz Bijeljine u Stepanovićevo i Sirig. Mađari su također smještani i u iseljena „dobrovoljačka sela“ u Baranjskom trokutu. Neki autori navode da je iz Gunje, Vučjaka, Brčkog i Bijeljine iseljeno 408 mađarskih obitelji, odnosno 1.631

16 HDA, Zavod za kolonizaciju NDH, kut. 325, br. 4891/44, br. 48917/44, br. 48980/44, br. $48916 / 44$, br. $48025 / 44$, br. $46050 / 44$, br. $45892 / 44$, br. $45972 / 44$, br. $45744 / 44$, br. $48921 / 44$; E. A Sajti, Hungarian Minority in the Vojvodina 1918-1947, str. 280-281; E. A. Šajti, Mađari $u$ Vojvodini 1918-1947, str. 173.

17 HDA, Zavod za kolonizaciju NDH, kut. 6, Zavod za kolonizaciju u Zagrebu, Broj Taj. 34181944, Opći propisnik o poslovanju Zavoda za kolonizaciju, Zagreb dne 20. srpnja 1944, str. 21.

18 HDA, Ministarstvo unutrašnjih poslova NDH (dalje MUP NDH), kut. 1, U.M.T. 1324/43.

19 N. Lazić, Baranja 1941-1945, str. 101-102; E. A. Sajti, Hungarian Minority in the Vojvodina 1918-1947, str. 282-283; E. A. Šajti, Mađari u Vojvodini 1918-1947, str. 174-175; S. D. Milošević, Izbeglice i preseljenici na teritoriji okupirane Jugoslavije 1941-1945, str. 9. 
osoba. ${ }^{19}$ Preseljenje je vodila MKZ uz pomoć podružnica s područja Srijema. Želja srijemskih Mađara za iseljavanjem, osobito tijekom 1943, kada su učestala partizanska djelovanja, nije podržana jer se očekivalo da će Srijem postati mađarsko državno područje, pa je stoga novosadski tisak poticao da se sakuplja pomoć u hrani, odjeći i lijekovima i tako ublaže nedaće Mađara na području NDH. MKZ je u ožujku 1943. tražila od MUP-a NDH dopuštenje za iseljavanje Mađara, te od Ministarstva udružbe da pokrije troškove preseljavanja (evakuacije) mađarskog stanovništva na sigurnija područja ,uslijed terora odmetnika“, što je i dopušteno. Mađari su se preseljavali/evakuirali iz Kutine u Čakovce u Srijemu, iz Humljana u Korođ, Laslovo, Hrastin, Retfalu, Čepin i Dalj u Slavoniji. ${ }^{20}$ Iz sela Zrinska iseljeno je u ožujku 1943. ,oko 200 kola“ uz pomoć domobranskih postrojbi. Preseljeni su u Marince, u vukovarskom kotaru, a iz Velikog i Malog Grđevca u Andrijaševce i Cernu na vinkovačkom području. ${ }^{21}$ Početkom ožujka 1943. s područja Podravske Slatine, a uz pomoć radnika na imanju grofa Draškovića, iselilo je preko mosta u Terezinom Polju ,više“" mađarskih obitelji s imovinom, odvodeći i brojnu stoku. Tijekom travnja 1943. u nekoliko željezničkih kompozicija iseljene su mađarske obitelji s područja Budakovaca, Crnog Zatona, Daruvara, Detekovca, Đulavesi, Garešnice, Grubišnog Polja, Novog Gradca, Pepelane, Rezovačke Krčevine i Terezinog Polja. Razlog je bio strah od napada partizana, kao i želja da izbjegnu regrutovanje u vojne postrojbe NDH. No, bila je to i neka vrsta „uzvraćanja“ za ponašanje mađarskih vlasti prema Hrvatima u Međimurju. Iseljavanja je bilo iz bjelovarskog kotara, iz sela Veliki i Mali Grđevac, Velika Barna i Zrinska. ${ }^{22}$

U konačnici proizlazi da se pitanje razmjene stanovništva između Mađarske i NDH, postavljeno već u travnju 1941, svodilo do kraja rata na rješavanje izbjegličkog pitanja. Tako je bilo i u veljači 1944. kada je mađarski izaslanik Marosy nastojao za mađarske preseljenike ishoditi da osim što mogu ponijeti sobom svoju imovinu, ostvare i pravo povratka na hrvatsko područje ukoliko se na to odluče. Hrvatska strana je načelno pristala i tražila da imovina onih koji se odluče ostati u Mađarskoj mora pripasti NDH. Mješovita mađarsko-hrvatska komisija još je raspravljala o uvjetima kada izbjeglice postaju iseljenici, te su u svibnju 1944. potpisale ugovor o izbjeglicama koji su se mogli kao državljani NDH vratiti u roku od dvije godine ili u protivnom uzeti mađarsko državljanstvo. S obzirom na stanje na bojištima obje su strane bile svjesne da se njihovi dogovori vrlo teško mogu provesti u stvarnosti, a sporazum o razmjeni stanovništva još nije bio utanačen. ${ }^{23}$

20 HDA, MUP NDH, U. M. 653/1943. od 20. ožujka 1943.

21 HDA, MUP NDH, U. M. Taj. br. 1323/1943 od 18. ožujka 1943 i U. M. 1331/43 od 8. lipnja 1943.

22 S. D. Milošević, Izbeglice i preseljenici na teritoriji okupirane Jugoslavije 1941-1945, str. 80-81.

23 E. A. Sajti, Hungarian Minority in the Vojvodina 1918-1947, str. 286; E. A. Šajti, Mađari u Vojvodini 1918-1947, str. 177. 
Na migracije mađarskog stanovništva, kako se rat bližio kraju, sve više utjecaja imao je partizanski pokret. Upadi partizana u mađarska sela od 1944, u pravilu, nisu okrenuta samo potrazi za hranom, već vrbovanjem muškog stanovništva u partizanske jedinice. Stoga su često mađarske izbjeglice tražile pomoć od mađarske i hrvatske vlasti, jer ukoliko se nisu željeli priključiti partizanima, protjerivali su ih bez mogućnost da ponesu imovinu. U rujnu 1944. $\mathrm{OZN}$-a za zagrebačku oblast u svom izvješću spominje osnivanje „organizacija za selenje“ u Mađarsku, u bjelovarskom i moslavačkom okrugu. Pripadnici OZN-e su još jednom brigadom proveli odabir stanovništva za preseljavanje na sljedeći način: „Koji Madjari imaju nekog u partizanima, tima ne dozvoljavamo selenje iz razloga, što bi im morali dati i njihov imetak, kojeg bi im Švabe opljačkali i upotrijebili za rat; oni Madjari, koji imaju nekog u neprijateljskoj vojsci proglašuju [se] narodnim neprijateljem i iseljava ih se bez razlike da li to oni hoće ili ne. Svi muškarci od takovih idu u konc. logor, oni pak koji nemaju nikog ni u bandi ni kod nas, a hoće da se sele, mogu da sele, ostavljajući imetak, a muškarci idu u logor; oni koji od takovih ne će da sele, moraju poslati sposobne muškarce u NOV-u. " ${ }^{24}$ Sličnih primjera bilo je i na đakovačkom području krajem 1944. Iz sela Drenje ,istjerane su neke ustaške, njemačke i madjarske familije“, a ,jedan drug ubio [je] iz puške“ jednog Mađara koji se nije htio seliti. ${ }^{25}$

Odluka da se muškarci između 16 i 50 godina ne mogu iseliti bitno je utjecala na odluku mađarskih obitelji o iseljavanju, kako pokazuje primjer na bjelovarskom području. U izvješću Kotarski komitet KP Hrvatske za Bjelovar navodi središnjici u Zagrebu: „Nakon odluke koja je donesena po odobrenju ZAVNOH-a o Mađarima, svi Mađari koji nisu krenuli do danas od svojih kuća, i koji nisu potpisali izjavu da se odriču svog imetka u korist naše države, odustali su od selenja za Mađarsku, i već su se mnogi izjasnili, koji su sposobni za vojsku, da su voljni da stupe u NOV, samo neka ih se ne tjera u Radne logore“. U studenom je bilo pokušaja da se mađarske obitelji isele u Mađarsku, ali kada je došlo do odvajanja muškaraca od 16 do 50 godina, nastala je mučna scena u kojoj se obitelji nisu htjele razdvojiti pa su ih zajedno otpremili u komandu grada i tada su muškarci „odmah počeli izjavljivati, da neka ih pustimo kući natrag, da će svi koji su sposobni stupiti u redove naše vojske [partizane] “. ${ }^{26}$

24 Partizanska i komunistička represija i zločini u Hrvatskoj 1944.-1946. Dokumenti (prir. Zdravko Dizdar, Vladimir Geiger, Milan Pojić, Mate Rupić), Slavonski Brod, 2005, Zagreb, 2009, str. 45-46; Partizanska i komunistička represija i zločini u Hrvatskoj 1944.-1946. Dokumenti. Slavonija, Srijem i Baranja, (prir. Vladimir Geiger, Mate Rupić, Zdravko Dizdar, Šimun Penava), Slavonski Brod, 2006, str. 87.

25 Partizanska i komunistička represija i zločini u Hrvatskoj 1944.-1946. Dokumenti, str. 51.

26 Mira Kolar-Dimitrijević, „Istjerivanje Mađara iz okolice Bjelovara 1944. godine“, ČSP, god. 27, br. 1/1995, str. 132-133.

27 Partizanska i komunistička represija i zločini u Hrvatskoj 1944.-1946. Dokumenti. Slavonija, Srijem i Baranja, str. 82. 
U studenom 1944. u kotaru Grubišno Polje politička situacija prema ocijeni OZN-e bila je „,dosta loša“. Ljudi su negodovali zbog ,,istjerivanja Mađara i Nijemaca“ iako je povjereništvo OZN-e na tom kotaru ,čestim mitinzima i dokazivanjima“ nastojalo uvjeriti stanovništvo da se je tako „moralo postupati“ jer se među Mađarima i Nijemcima „,osjetila peta kolona“. ${ }^{27}$ U kotaru Garešnica povjereništvo OZN-e u navelo je u svom izvješću da su se brojni članovi mjesnih NOO zalagali za ostanak pojedinih ,mađarskih familija“ koje su morale iseliti, no, samo je u nekoliko slučajeva to i uspjelo jer je utvrđena ,manjkavost dobivenih podataka“" na temelju kojih su morali iseliti. S područja Pakraca i Lipika također su brojni Mađari protjerani ,preko Drave“ te su ostali živjeti u Mađarskoj ili su iselili u Australiju i Sjedinjene Američke Države. ${ }^{28}$

Preslikano stanje bilo je i na području Srijema. Podružnice MKZ-a s toga područja javljale su centru u Zagreb da partizani sve više vrše pritisak na Mađare da stupe u njihove redove, pa ih čak na to i prisiljavaju. No, prve su na redu partizanima ipak bile njemačke i hrvatske obitelji koje su i same bježale pred dolaskom partizana, a prema procjenama Mađara, Nijemci i Hrvati imali su „bolji položaj“ jer su bili naoružani. Stoga su Mađari iz Srijema poslali u Zagreb u siječnju 1944. svoje izaslanstvo koje je zatražilo da se Mađari u potpunosti presele u Mađarsku. Do toga nije došlo zbog političkih promjena u ožujku 1944. u Mađarskoj, a kasnije i vojnog prodora Crvene armije i jugoslavenskih partizana, posebice prema srijemskom području. ${ }^{29}$

Mađarsko stanovništvo na području NDH, u pravilu seosko, nastojalo je osigurati „neutralnost“ i bilo spremno na suradnju s NOV i PO Jugoslavije/JA opskrbljivanjem hranom, ali ne i ulaskom u partizanske postrojbe. No, partizanska strana dala im je mogućnost ili mobilizacija ili iseljavanje bez imovine, jer su ,pripadnici neprijateljske zemlje“. Stalna je bila i bojazan od njihovih ,težnji“ da Mađarska okupira sjeverni dio Hrvatske ,isto onako kao što je okupirala Međimurje“. Bilo je i onih u partizanskim redovima koji su pokazivali više razumijevanja za mađarsko stanovništvo i koji su smatrali da bi ih trebalo više „ekonomski opteretiti“ i ne nužno nasilno regrutovanje, no, taj model se ipak nije primijenio jer je prevladalo mišljenje da kao neopredijeljeni predstavljaju „,nepouzdan element“. ${ }^{30}$ Odnos prema mađarskom stanovništvu nije se primijenio niti u poslednjoj godini rata. U ožujku 1945. na moslavačkom području prema izvješću OZN-e iseljeni su iz općine Narta svi Mađari jer su se „neprijateljski

28 Partizanska i komunistička represija i zločini u Hrvatskoj 1944.-1946. Dokumenti. Zagreb $i$ središnja Hrvatska, (prir. Vladimir Geiger, Mate Rupić, Mario Kevo, Egon Kraljević, Zvonimir Despot), Slavonski Brod - Zagreb, 2008, str. 124; Dragutin Fezi, „Mađari u pakračkom kraju“, Zbornik Povijesnog društva Pakrac - Lipik, br. 6/2009, str. 87.

29 A. Kasaš, Mađari u Vojvodini 1941-1946, str. 127-129.

30 M. Kolar-Dimitrijević, „Istjerivanje Mađara iz okolice Bjelovara 1944. godine“, str. 127-130.

31 HDA, Odjeljenje zaštite naroda (OZNA) za Hrvatsku, kut. 13, 4.0. POC za Gornju Hrvatsku, str. 287. 
odnosili prema NOP-u“, a članovi njihovih obitelji bili su u „,neprijateljskoj vojsci““. ${ }^{31}$

Kao primjer umjerenijeg postupka prema Mađarima izdvaja se djelovanje Franje Gažija, jednog od značajnijih članova Hrvatske seljačke stranke i člana ZAVNOH-a. On je na bjelovarskom području u jesen 1944. odgovarao mađarsko stanovništvo od iseljavanja, te upozorio Okružni komitete KPH za Bjelovar da takav odnos prema Mađarima uznemirava i Hrvate i Srbe na tom području jer se boje da će se i njima isto dogoditi ako „ne idu u partizane“. ${ }^{32}$ I Vojna uprava za Banat, Bačku i Baranju Narodnooslobodilačke vojske Jugoslavije u prosincu 1944. utvrđuje da su se u odnosu prema Mađarima i Nijemcima događali u ,nizu mjesta i sela nepravilni postupci koji samo bacaju ljagu na naše vojne organe i štete interesima našeg naroda i naše države“. Zapovjeđeno je komandama vojnih oblasti, područja, mjesta i vojnih stanica ,pravilan i jedinstven“ postupak prema Mađarima i Nijemcima, a na temelju odluka Drugog zasjedanja AVNOJ-a koje nacionalnim manjinama jamče ravnopravan položaj. U skladu s tim tražili su da se raspuste svi logori „,sastavljeni od Mađara“ odnosno u logoru su se mogli zadržati samo „okrivljenici“ pod istragom sudskih organa i oni koji su već kažnjeni od strane nadležnog vojnog suda. Odgođeno je regrutovanje Mađara, osim na dobrovoljnoj osnovi jer još nije bila provedena „opća mobilizacija“. Mađarsko muško stanovništvo od 18 do 30 godina ukoliko se nije priključilo NOV-u, otpremano je u radne jedinice. ${ }^{33}$

Mađarsko stanovništvo će intenzivnije od 1943. uzeti više učešća u NOP-u jer su od tada bili jače izloženi utjecajima Komunističke partije. Dolazak mađarskih antifašista koji su se priključili partizanskim postrojbama, kao što je to bio primjer u Srijemu, te simbolično ustrojavanje bataljuna „Šandor Petefi“ ("Sándor Petőfi") u kolovozu 1943. u Slavoniji, pridonio je priključivanju Mađara partizanskim jedinicama. Odaziv Mađara s područja Baranje i Bačke u partizanske jedinice bio je manji. ${ }^{34}$

Velika evakuacija stanovništva i materijalnih dobara s područja Slavonije, i u manjem broju iz zagrebačke oblasti, provedena je početkom siječnja 1945. pod vodstvom narodnooslobodilačkih odbora. Zbjeg oko 15.000 ljudi prvo je smješten u Mađarsku, a potom u Vojvodinu. Nacionalni sastav izbjeglica poznat je samo za područje oblasti Slavonski Brod. Među evakuiranim najbrojniji su bili

32 M. Kolar-Dimitrijević, „Istjerivanje Mađara iz okolice Bjelovara 1944. godine“, str. 130.

33 Partizanska i komunistička represija i zločini u Hrvatskoj 1944.-1946. Dokumenti. Slavonija, Srijem i Baranja, str. 85.

34 Ljubiša Stojković, Miloš Martić, Nacionalne manjine u Jugoslaviji, Beograd, 1953, str. 46-47; A. Kasaš, Mađari u Vojvodini 1941-1946, str. 129; M. Kolar-Dimitrijević, „Istjerivanje Mađara iz okolice Bjelovara 1944. godine“, str. 127-128 i 133-134.

35 Srećko Ljubljanović, „Evakuacija stanovništva Slavonije u Mađarsku i Vojvodinu početkom 1945“, Zbornik, Historijski institut Slavonije, br. 4, Slavonski Brod, 1966, str. 22, 24 i 29. 
Hrvati i Srbi te manji broj Mađara, Rusina, Bugara, Poljaka, Nijemaca i dr. Za pretpostaviti je da je mađarskog stanovništva bilo u zbjegu i iz drugih slavonskih područja. ${ }^{35}$

36 Radmila Radić, „Iseljavanje stanovništva sa jugoslovenskog prostora polovinom pedesetih godina“, Istorijski zapisi, br. 1-2/1999, str. 143-144; Mladenka Ivanković, Jevreji u Jugoslaviji. Kraj ili novi početak (1944-1952), Beograd, 2009, str. 299-355; Slobodan Selinić, Jugoslovensko-čehoslovački odnosi 1945-1955, Beograd, 2010, str. 333-351; Aleksandar R. Miletić, „(Extra-)Institutional Practieces, Restrictions, and Corruption. Emigration Policy in the Kingdom of Serbs, Croats, and Slovenes (1918-1928)“, Transnational Societies, Transterittorial Politics. Migration in the (Post) Yugoslav region, 19th - 21st Century, (ed. Ulf Brunnbauer), München, 2009, str. 108-112; Edvin Pezo, ,'Re-Conquering' Space. Yugoslav Migration Policies and the Emigration of Non-Slavic Muslims to Turkey (1918-1941)“, Transnational Societies, Transterittorial Politics. Migration in the (Post) Yugoslav region, 19th - 21st Century, str. 73-94.

37 Etničko čišćenje. Povijesni dokumenti o jednoj srpskoj ideologiji (prir. Mirko Grmek, Marc Gjidara, Neven Šimac), Zagreb, 1993, str. 152-154; Vladimir Geiger, Folksdojčeri. Pod teretom kolektivne krivnje, Osijek, 2002, str. 41-55; E. A. Sajti, Hungarian Minority in the Vojvodina 1918-1947, str. 443-446; E. A. Šajti, Mađari u Vojvodini 1918-1947, str. 269-271; Zdenko Radelić, Hrvatska u Jugoslaviji 1945.-1991. Od zajedništva do razlaza, Zagreb, 2006, str. 48; Zoran Janjetović, „Proterivanje nemačkog i mađarskog življa iz Vojvodine na kraju Drugog svetskog rata“, Hereticus, vol. 5, br. 1, Beograd, 2007, str. 113. 


\section{Iseljavanje i protjerivanje mađarskog stanovništva s hrvatskog područja poslije rata}

Jugoslavija je bila državna tvorevina koja se tijekom svog postojanja rješavala manjina. U Kraljevini SHS/Kraljevini Jugoslaviji ciljane grupe bile su nacionalne skupine koje su naseljavali Habsburška monarhija/Austro-Ugarska i Osmansko carstvo, a poslije Drugog svjetskog rata „ostaci ostataka“ tog stanovništva, ali i druge nacionalne i etničke skupine, ponovo su na udaru iseljavanja. ${ }^{36}$

Komunističke vlasti Jugoslavije su još za vrijeme trajanja rata, a i nakon toga razrađivale planove o iseljavanjima i razmjeni stanovništva. U historiografiji su poznata tri plana o rješavanju pitanja pojedinih nacionalnih manjina. Vasa Čubrilović, u studenom 1944, predlagao je protjerivanje svih manjina koje su bile „nelojalne“ tijekom rata. Sreten Vukosavljević zalagao se za izgon 80.000 do 200.000 Mađara uz ustupanje dijela jugoslavenskog područja Mađarskoj, kao i protjerivanje i onemogućavanje povratka u Jugoslaviju Nijemaca, a u Sloveniji je Slovensko narodnooslobodilačko vijeće/Slovenski narodnoosvobodilni svet potaknulo raspravu o nužnosti protjerivanja Nijemaca. ${ }^{37}$

Čubrilovićev nacrt nije u konačnici izvršio izravan utjecaj na rješenje pitanja mađarske manjine u Jugoslaviji, ali je utoliko značajan što je autor ubrzo nakon toga postao ministar poljoprivrede, a njegova rješenja bila su na tragu prijeratnih stavova određenih krugova u Srbiji koji su bili za „etnički čistu“ Vojvodinu i Kosovo. Poslije rata Vukosavljević kao ministar za kolonizaciju poslao je u rujnu 1945. svoj memorandum Edvardu Kardelju i Milovanu Đilasu kao odgovornim osobama za ideološki i propagandni rad Komunističke partije Jugoslavije u kojem je izrazio sumnju o mađarskoj manjini u Jugoslaviji kao sponi dviju država jer je sumnjao, kao i kod njemačkog stanovništva, u njihovu mogućnost da prihvate novu državnu stvarnost. Izrazio je i mišljenje da se Mađari ne mogu iseliti na neko drugo područje unutar Jugoslavije, ali da se mora spriječiti „mađarizacija Vojvodine“ dodjeljivanjem zemlje Mađarima. S druge strane Vukosavljević navodi da ako Mađari ostanu, ne mogi biti diskriminirani u podjeli zemljišnih posjeda te da će u tom slučaju biti „,iscrpljene zalihe“ zemlje za „,naše veterane i njihove obitelji“. Maksimalističke Mađara, njih oko 200.000, za ise-

38 E. A. Sajti, Hungarian Minority in the Vojvodina 1918-1947, str. 443-446; E. A. Šajti, Mađari u Vojvodini 1918-1947, str. 269-270; Z. Janjetović, „Proterivanje nemačkog i mađarskog življa iz Vojvodine na kraju Drugog svetskog rata“, str. 113.

39 E. A. Sajti, Hungarian Minority in the Vojvodina 1918-1947, str. 450 i 446; E. A. Šajti, Mađari u Vojvodini 1918-1947, str. 275 i 271; A. Hornyák, „Jugoslavenski teritorijalni zahtjevi prema Mađarskoj i susjednim zemljama i planovi za njihovu primjenu nakon Drugog svjetskog rata“, str. 44 i 50.

40 E. A. Sajti, Hungarian Minority in the Vojvodina 1918-1947, str. 447 i 455; E. A. Šajti, Mađari u Vojvodini 1918-1947, str. 272 i 278.

${ }^{41}$ M. Kolar-Dimitrijević, „Istjerivanje Mađara iz okolice Bjelovara 1944. godine“, str. 130, 131 i 133. 
ljenjem prijetilo je traženjem teritorijalnih ustupaka od strane Mađarske, pa je Vukosavljević kao prvo rješenje tražio zamjenu stanovništva - 80.000 Mađara za 20.000 Hrvata i 6.500 Srba. Nije pristao na ideju da se kotarevi s bunjevačkim i mađarskim stanovništvom izdvoje i pripoje Hrvatskoj jer to neće smanjiti „osjećaj straha od Mađara" u Srbiji. ${ }^{38}$

Poslije rata Jugoslavija i Mađarska razmatrale su mogućnost razmjene stanovništva isprva na bazi reciprociteta jer je iz Jugoslavije trebalo otići 300.000 Mađara za upola manji broj Jugoslavena iz Mađarske. To je trebalo konačno definirati nakon mađarsko-čehoslovačkog dogovora o razmjeni stanovništva. U kolovozu 1946. jugoslavenska strana predložila je razmjenu do 40.000 osoba na bazi reciprociteta i načelu dobrovoljnosti, što je načelno prihvatila i mađarska strana 12. rujna 1946. Mađari su u istovremenom pokretanju pitanja razmjene stanovništva od strane Čehoslovačke i Jugoslavije vidjeli neku vrstu slavenske urote protiv Mađara. ${ }^{39}$

Tijekom 1946. bilo je pokušaja s mađarske strane da se raspršena mađarska manjina u Hrvatskoj preseli u Mađarsku, no, ideja nije zaživjela u visokim političkim krugovima u Mađarskoj, pa je stoga jugoslavenska strana nije ni razmatrala. Od Mađara je zatraženo da prihvate mađarske obitelji koje su s područja NDH, odnosno iz Bosne, tijekom rata naseljene u Bačkoj. ${ }^{40}$

Imovina izbjeglog mađarskog stanovništva, kao i onih koji su sami otišli s jugoslavenskog područja je konfiscirana. U slučajevima da se dio obitelji iselio u Mađarsku, a dio ostao, oni koji su se odlučili na ostanak prema sugestiji vlasti iseljavani su u Mađarsku. Pošteđeni su mogli biti oni koji su mogli dokazati da „imaju nekoga u partizanima“. ${ }^{41}$ Česti su slučajevi da povjerenici koji su morali čuvati napuštenu mađarsku imovinu nisu izvršavali svoju zadaću. Bilo je primjera da su članovi komisija za iseljavanje okružnih NOO-a i povjerenici za čuvanje imovine na svojim poslovima većinom bili u „pripitom stanju“ i nije im bilo strano otuđivanje imovine. ${ }^{42}$

42 Partizanska i komunistička represija i zločini u Hrvatskoj 1944.-1946. Dokumenti. Zagreb i središnja Hrvatska, str. 124-125.

43 Partizanska i komunistička represija i zločini u Hrvatskoj 1944.-1946. Dokumenti. Slavonija, Srijem i Baranja, str. 85-86; Goran Miloradović, Karantin za ideje. Logori za izolaciju „sumnjivih elemenata “ u Kraljevini Srba, Hrvata i Slovenaca 1919-1922, Beograd, 2004, str. 79; Z. Janjetović, „Proterivanje nemačkog i mađarskog življa iz Vojvodine na kraju Drugog svetskog rata", str. 111.

44 Partizanska i komunistička represija i zločini u Hrvatskoj 1944.-1946. Dokumenti, str. 45-46; Partizanska i komunistička represija i zločini u Hrvatskoj 1944.-1946. Dokumenti. Slavonija, Srijem i Baranja, str. 374-375.

${ }^{45}$ Jugoslavensko nasilje i prešućivane žrtve Drugoga svjetskoga rata i poraća s područja današnje Bjelovarsko-bilogorske županije (prir. Zdravko Ivković, Josip Vusić, Anita Blažeković), Bjelovar, 2010, str. 717-719 i 725.

46 HDA, Zagreb, Javno tužilaštvo Socijalističke Republike Hrvatske, 5/128; Partizanska i komunistička represija i zločini u Hrvatskoj 1944.-1946. Dokumenti, str. 230; Partizanska i komunistička represija i zločini u Hrvatskoj 1944.-1946. Dokumenti. Zagreb i središnja Hrvatska, str. 554. 
Tijekom Drugog svjetskog rata, a posebice nakon rata, komunističke su vlasti imale svoje logore za internaciju vojnih zarobljenika, političkih protivnika, te nepoželjnih nacionalnih skupina.

Zatvaranje mađarskog stanovništva u logore, u prvo vrijeme potkraj Drugog svjetskog rata te u neposrednom poraću, veže se za sudbinu njemačkog stanovništva. U jesen 1944. Mađari su na području Vojvodine zatvarani u logore, no ubrzo počinju masovnija otpuštanja. Oni koji nisu bili u logorima odlazili su svakodnevno na „prinudni rad“. Vojna uprava za Banat, Bačku i Baranju NOV Jugoslavije naredila je 1. prosinca 1944. komandama vojnih oblasti, komandama područja, mjesta i drugim vojnim nadleštvima da se raspuste svi logori za Mađare i da se mogu zadržati samo oni Mađari koji su pod istragom sudskih organa ili su već osuđeni. ${ }^{43}$

$\mathrm{Na}$ hrvatskom području u rujnu 1944. kada se raspravljalo o kriterijima iseljavanja mađarskog stanovništva navodi se da će se mađarsko stanovništvo koje je imalo nekoga u neprijateljskoj vojsci morati iseliti u Mađarsku, a muškarce je trebalo otpremiti u „konc. logor“". Oni koji su se sami odlučili iseliti, a nisu imali nikoga u neprijateljskoj vojsci ili partizanima, morali su se odreći imovine, a muškarce je trebalo otpremiti u logore. Mjesto ili mjesta gdje su se nalazili logori citirani dokument ne navodi. U ljeto 1945. još se na hrvatskom području $\mathrm{u}$ dokumentima navodi otpremanje Mađara u logore jer je njihov povratak iz Mađarske stvarao socijalne probleme. Njihovi posjedi već su bili kolonizirani, pa im nisu mogli biti vraćeni. ${ }^{44}$

Jedan od sabirnih logora za hrvatske Mađare bio je u Velikoj Pisanici kod Bjelovara. U logor su internirani Mađari iz Bjelovara i okolice. ${ }^{45}$ Početkom srpnja 1945. u sabirnom logoru u Velikoj Pisanici nalazilo se ukupno 813 osoba, od toga 185 Nijemaca i Mađara. ${ }^{46}$

Blaži odnos prema mađarskom stanovništvu, za razliku od krutog odnosa prema njemačkom stanovništvu, potvrđuje i odluka Državne komisije za repatrijaciju, iz svibnju 1945, da se mogu repatrirati svi jugoslavenski građani mađarske nacionalnosti koji se nisu ogriješili u ratu protiv jugoslavenske države. ${ }^{47}$ To se može protumačiti općenito jačom percepcijom Nijemaca kao krivaca u

47 Partizanska i komunistička represija i zločini u Hrvatskoj 1944.-1946. Dokumenti, str. 156-157.

48 Z. Janjetović, „Proterivanje nemačkog i mađarskog življa iz Vojvodine na kraju Drugog svetskog rata“, str. 112-113 i 116.

49 Milko Mikola, Dokumenti in pričevanja o povojnih izgonih prebivalstva v Sloveniji, Ljubljana, 2009, str. 85-104.

50 E. A. Sajti, Hungarian Minority in the Vojvodina 1918-1947, str. 437-438; E. A. Šajti, Mađari u Vojvodini 1918-1947, str. 265.

51 Arhiv Jugoslavije (dalje AJ), Beograd, Predsjedništvo vlade FNRJ, 35-717; Partizanska i komunistička represija i zločini u Hrvatskoj 1944.-1946. Dokumenti, str. 156; Partizanska i komunistička represija i zločini u Hrvatskoj 1944.-1946. Dokumenti. Zagreb i središnja Hrvatska, str. 414-415. 
Drugom svjetskom ratu, te vanjskopolitičkim potrebama, odnosno jugoslavenskim doprinosom, na poticaj SSSR-a, izgradnji komunističke Mađarske. Nije zanemariv niti podatak da su Mađari, za razliku od Nijemaca, bili većinom sitni zemljoposjednici i bezemljaši. ${ }^{48}$ No da je jugoslavenska vlast bila nepovjerljiva prema mađarskoj manjini pokazuje slučaj mađarskog sela Petišovci u Prekmurju, u Sloveniji, koje je u prosincu 1948. i travnju 1949. raseljeno, a 215 obitelji imale su rok od tri dana da se isele. Vlasti su svoju odluku opravdavale ,tehničkim razlozima“ jer se tamo nalazila bušotina nafte, no, mađarsko stanovništvo slutilo je da ih se raseljava zbog bojazni od ,sabotaža“. Uputstvo je bilo, nakon što su dobili naknadu za napuštenu imovinu, da samo odaberu mjesto u koje će iseliti, a ako se tko sam „ne snađe“, vlasti bi u tomu slučaju pružile pomoć. ${ }^{49}$

Prema nekim navodima poslije rata je oko 15.000 Mađara iz Međimurja i Prekomurja internirano, a znatan broj ih je naseljen u Bosni. Bilo je i izgona preko granice, a prema nekim svjedočenjima u svibnju 1945. oko 1.200 Mađara pješke je protjerano iz Međimurja u Mađarsku. ${ }^{50}$ Položaj mađarskog stanovništva u neposrednom poraću u Jugoslaviji i Hrvatskoj bio je bitno određen djelovanjem Državne komisije za repatrijaciju, koja je djelovala unutar Ministarstva socijalne politike i predlagala mjere iseljavanja/protjerivanja pripadnika njemačke i mađarske narodnosti. U svibnju 1945. ta je komisija poslala Predsjedništvu Ministarskog savjeta i Generalštabu Jugoslavenske armije na usuglašavanje sljedeći prijedlog: „Izvršiti repatrijaciju svih bivših jugoslavenskih državljana mađarske narodnosti, a po tom s njima postupati prema njihovom držanju i radu za vreme rata i okupacije naše zemlje od strane fašističkih sila. One, koji se ničim nisu ogrešili o svoje dužnosti prema zemlji čije su državljanstvo imali, pustiti njihovim kućama, a one koji su se, dobrovoljnom službom u fašističkoj vojnoj sili ili na bilo koji drugi način, ogrešili o zemlju za čije su pripadnike smatrani uzeti na odgovornost." ${ }^{51}$

Ministarstvo vanjskih poslova je 30. lipnja 1945. poslalo strogo povjerljiv dopis Ministarstvu socijalne politike u kojem traže revidiranje stava oko povratka svih jugoslavenskih državljana mađarske narodnosti, a u kojem se navodi sljedeće: „u ovom momentu kada se sa toliko teškoća radi na repatrijaciji naših državljana, koji su kao žrtve fašizma na razne načine odvedeni iz zemlje, nema političkih razloga da se donosi i jedna odluka, koja bi još više komplikovala ovaj već sada obiman posao, a po kojoj bi se insistiralo na povraćaju svih ju-

52 AJ, Predsjedništvo vlade FNRJ, 35-723, 35-1032, 35-1040-1044.

53 Tibor Cseres, Krvna osveta u Bačkoj, Zagreb, 1993; Andrija Bognar, „Položaj Mađara u Vojvodini od 1918. do 1995.“, Jugoistočna Europa 1918.-1995. (prir. Aleksander Ravlić), Zagreb, 1996, str. 95-96.

54 Partizanska i komunistička represija i zločini u Hrvatskoj 1944.-1946. Dokumenti. Slavonija, Srijem i Baranja, str. 374-375.

55 Partizanska i komunistička represija i zločini u Hrvatskoj 1944.-1946. Dokumenti. Zagreb i središnja Hrvatska, str. 542 i 543. 
goslavenskih državljana mađarske narodnosti. Ne sme se izgubiti iz vida da su veliki broj tih ljudi ili oni koji su se stavili u službu mađarskom fašizmu, ili pak oni koji su se zbog svog izrazito fašističkog stava u jesen 1944. god. izbegli pred ruskom i našom armijom, plašeći se odgovornosti. [...] Pri tom, pošto je teror mađarske manjine nad jugoslavenskim stanovništvom bio masovan, vanredno teško će biti dokazati pojedincima krivicu i odgovornost čak i za slučaj, gde je njihova fašistička delatnost nesumnjiva, pa Jugoslavija nema razloga da insistira na njihovom povratku utoliko pre, što zato nema spoljno-političkih razloga. [...] Za sve od njih [...] koji bi sigurnim dokazima mogli dokazati svoje aktivno učešće u Narodno oslobodilačkom pokretu [...] postoji mogućnost da se ispitivanje ovakvih slučajeva poveri našoj delegaciji pri S.[avezničkoj] K.[ontrolnoj] K.[omisiji] u Budimpešti [...]. Pri tom je samo važno to, da se ova ocena vrši na mađarskoj teritoriji, a ne na našoj, pošto im se već dopustio ulazak. ${ }^{\text {"52 }}$

Ovakvo stajalište otvaralo je mogućnost da se brojno mađarsko stanovništvo poziva „na odgovornost“, što je zasigurno stvaralo među njima nelagodu koja je u konačnici bila i prihvatljiva cijena ukoliko posljedice nisu bile drastičnije (logori, smaknuća i sl.). Osobito su poduzete drakonske mjere protiv Mađara, u ime ratnih stradanja Srba tijekom rata, na području Bačke. ${ }^{53}$ U kolovozu 1945. javni tužitelj virovitičkog okruga izvijestio je Jakova Blaževića, javnog tužitelja Hrvatske, da prema uputstvu Save Zlatića iz CK SKH mađarskom stanovništvu koje je samo otišlo u Mađarsku prije oslobođenja ili je protjerano zbog ,neprijateljskog odnošaja prema NOP-u“, a tada se vraćalo u Hrvatsku, ne vraćaju imovinu i otprema ih se u logore. Tražilo se da se potvrdi ovakav postupak ili da se ponudi „drugo rješenje“. ${ }^{54}$ Bilo je Mađara, kao i Hrvata, Srba i Čeha, koji su se učlanjivali tijekom rata u Njemačku narodnu skupinu što je bilo motivirano boljim položajem, osobito u smislu opskrbe, i po toj osnovi su poslije rata suđeni ili su se morali iseljavati. ${ }^{55}$

Još su tijekom 1947. Mađarska i Jugoslavija rješavale neka pitanja oko repatrijacije. Radilo se o repatrijaciji mađarske djece koja su tijekom rata bila sklonjena na jugoslavensko područje zbog savezničkih zračnih napada na Mađarsku, te jugoslavenske djece iz Mađarske koja su tamo stigla kao izbjeglice. ${ }^{56}$

Zanimljiv je i primjer Mađara koji su na jugoslavensko područje došli nakon sloma Mađarske Sovjetske Republike, a poslije rata su htjeli ili morali iseliti. MUP NR Hrvatske u prosincu 1947. poslao je uputu svim kotarskim i gradskim narodnooslobodilačkim odborima (NO) i Oblasnom NO Dalmacija da se prema Zakonu o otpustu iz jugoslavenskog državljanstva molbe upućuju NO-ima, osim u slučaju mađarskih emigranata koji su poslije sloma mađarske

56 AJ, Predsjedništvo vlade FNRJ, 35-958-962.

57 Državni arhiv u Osijeku, Sabirni centar Vinkovci, Gradski NO Vinkovci, Pov. spisi 1947.

58 A. Hornyák, „Jugoslavenski teritorijalni zahtjevi prema Mađarskoj i susjednim zemljama i planovi za njihovu primjenu nakon Drugog svjetskog rata“, str. 48, 49-50 i 52. 
revolucije 1919. emigrirali u Jugoslaviju i stekli državljanstvo. Njihove molbe posebno su rješavane, a razlog tomu bila je vjerojatno veća sklonost prema onima koji su nakon sloma Mađarske Sovjetske Republike došli na jugoslavensko područje. ${ }^{57}$

Unatoč mađarsko-jugoslavenskim razmiricama Britanci su navodili da su Mađari već 1946. isticali kao pozitivan primjer uređenje odnosa prema mađarskoj nacionalnoj manjini u Jugoslaviji i da bi isti trebala primijeniti i Čehoslovačka prema svojim Mađarima. Bio je to način na koji su jugoslavenske vlasti nastojale pripomoći učvršćenju komunističkog poretka u Mađarskoj. Čehoslovačka strana bila je u ljeto 1946. nezadovoljna razmjenom i nagovijestila protjerivanje mađarskog stanovništva, a 16. kolovoza 1946. bez prethodnih najava, u svrhu jačeg pritiska na Mađarsku, i Jugoslavija potiče razgovore o razmjeni stanovništva naglašavajući „ugnjetačku politiku stare Mađarske i revizionističku politiku Hortijeva režima“, zatim povredu ugovora o „vječnom prijateljstvu“ iz 1940. i mađarske zločine počinjene za vrijeme Drugog svjetskog rata na područjima koja je zaposjela. Dogovori o razmjeni stanovništva između Mađarske i Jugoslavije nisu provedeni jer je to jugoslavenska strana u određenom trenutku tražila kao podršku Čehoslovačkoj u iseljavanju Mađara iz Slovačke, a prema nekima i zbog nastojanja da se legalizira iseljavanje Nijemaca. ${ }^{58}$

\section{Zaključak}

Do sukoba jugoslavenskog državnog vodstva s Informbiroom percepcija Mađarske u Hrvatskoj bila je vrlo pozitivna i prijateljska s tim da se naglašavalo postojanje dvije Mađarske. „Stare“ koje su vodili pripadnici „mađarske imperijalističke klike" i uz koju jugoslavenske narode veže negativno iskustvo iz ranije i neposredne prošlosti i ,nove“ demokratske i progresivne s kojom jugoslavenska komunistička vlast razvija prijateljske odnose. Novija istraživanja pokazuju da se ,protumađarska agitacija“ javila i znatno ranije u Glasu, glasilu Srpskog narodnog fronta, Politici i Borbi, a što je prema nekim tumačenjima bilo ,izražavanje

59 A. Hornyák, ,Jugoslavenski teritorijalni zahtjevi prema Mađarskoj i susjednim zemljama i planovi za njihovu primjenu nakon Drugog svjetskog rata“, str. 45-46.

60 AJ, Predsjedništvo vlade FNRJ, 35-1075; A. Kasaš, Mađari u Vojvodini 1941-1946, str. 129; Marijan Maticka, ,Slika o Austriji i Mađarskoj na stranicama središnjih hrvatskih novina (1945.1950.), Internationales kulturhistorisches Symposion Mogersdorf - International Historico-Cultural Symposium Mogersdorf, Hrvatski referenti 1972.-2004., Zagreb, 2005 /CD ROM/.

${ }^{61}$ Lj. Stojković, M. Martić, Nacionalne manjine u Jugoslaviji, str. 173-174; Vladimir Stipetić, „Jedno stoljeće u razvoju nacionalne strukture stanovništva n teritoriju SR Hrvatske (18801981)“, Suvremeni ekonomski problemi, br. 8, Zagreb, 1987, 106; M. Kolar-Dimitrijević, „Istjerivanje Mađara iz okolice Bjelovara 1944. godine“, str. 126; E. A. Sajti, Hungarian Minority in the Vojvodina 1918-1947, str. 434 i 440.; E. A. Šajti, Mađari u Vojvodini 1918-1947, str. 263 i 267; Bilogorai magyarok/Mađari Bilogore (ur. Tünde Sipos Zsivics), Pélmonostor/Beli 
averzije“ jugoslavenskih komunista prema stranici Malih posjednika koja je pobijedila na izborima u Mađarskoj. ${ }^{59}$ Nakon rezolucije IB-a i suđenja Lászlu Rajku, nekadašnjem ministru unutarnjih i vanjskih poslova, koji je optužen da u sprezi s jugoslavenskim komunističkim vodstvom radi na ,protumađarskoj liniji“, jugoslavenska/hrvatska javnost otada je imala izrazito negativan stav prema Mađarskoj. Dovodio se u pitanje i ispravan odnos prema nacionalnim manjinama u Mađarskoj, slovenskoj, hrvatskoj i srpskoj, a mađarska radnička klasa i narod prikazivani su kao ,zarobljenici“ u ,staljinističko-informbirovskim“ lancima. Mađarski komunisti koji su prebjegli u Jugoslaviju imali su na području Narodne Republike Hrvatske bazu za prihvat u Petrinji. Jugoslavenska je strana, nakon sukoba s IB-om, manji odaziv mađarskog stanovništva u partizanske jedinice, na području Baranje i Bačke, pripisivala ne samo mađarskom zaposjedanju toga područja već i ,izdajničkim držanjem“ Komunističke partije Mađarske koja je podržavala okupaciju kao ispravljanje ,,versajske nepravde““6 ${ }^{60}$

Drastičan pad udjela mađarskog stanovništva na jugoslavenskom i hrvatskom prostoru započeo je poslije Prvog svjetskog rata kad je oko 45.000 Mađara napustilo jugoslavensko područje. Poslije Drugog svjetskog rata, krajem 1946, prema popisu izbjeglica u Mađarskoj, 84.800 izbjeglica bilo ih je iz Jugoslavije, a prema popisu stanovništva 1949. godine 65.877 Mađara izjasnilo se da je porijeklom iz Jugoslavije. Unutarnja struktura izbjeglih i protjeranih Mađara s jugoslavenskog područja nije poznata, pa je teško utvrditi točan broj Mađara koji je otišao s hrvatskog područja, no, procjena je da ih je oko 7.000 napustilo Hrvatsku. Na njihove posjede većinom su naseljeni Srbi. Osim iseljavanja, tijekom i poslije ratnih sukoba, izravni utjecaj na opadanje broja stanovnika imaju i ljudski gubici, pa tako i u slučaju mađarskog stanovništva. Prema popisu stanovništva 1948. na hrvatskom prostoru ostalo je 51.399 Mađara, pretežno u Baranji, na osječkom i bjelovarskom području. U kasnijim popisima broj mađarskog staovništva neprekidno se smanjivao. ${ }^{61}$

Asimilacija mađarskog stanovništva u razbacanim mađarskim naseljima započela je već prije Prvog svjetskog rata, te se nastavila i kasnije, a bila je potaknuta i nedostatkom obrazovanja na materinjem jeziku, osobito na području zapadno od Osijeka. Brojni miješani brakovi razlog su što se veliki broj Mađara, posebice u gradskim sredinama, asimilirao s većinskim narodom. Mađarsko stanovništvo koje je odlučilo nakon Drugog svjetskog rata ostati ili pak nije uspjelo prijeći u Mađarsku ili se željelo i uspjelo vratiti u Hrvatsku, dijelilo je u kasnijem razdoblju, u pogledu migracija, sudbinu većinskog naroda. Tako je znatan broj

Manastri-Pecs/Pečuh, 2008, str. 9, 10 i 16; Zoran Janjetović, „Die Ungarische Minderheit in Jugoslawien 1944-1956“, Vom Faschismus zum Stalinismus. Deutsche und andere Minderheiten in Ostmittel- und Südosteuropa 1941-1953 (Hrsg. Mariana Hausleitner), München, 2008, str. 161 i 162.

${ }^{62}$ Bilogorai magyarok/Mađari Bilogore, str. 10. 
Mađara šezdesetih godina 20. stoljeća iskoristio priliku za odlazak na privremeni rad u zapadnoeuropske zemlje i nisu se od tamo vratili. ${ }^{61}$

Mimikrija je bila neka vrsta zaloga za bolje uklapanje u sredinu i u velikom broju slučajeva svodila njihov identitet na „kriptomađarski““.

\section{Summary}

Dr Marica Karakaš Obradov

\section{The Migrations of Hungarian National Group during the Second World War and in the Post-War Period in Croatia}

Key words: Second World War, ,people's democracy“, Independent State of Croatia, Croatia, Hungarians, migrations, settlements, evacuations, refugees, deportations

Exchange of population had been a permanent subject of discussions between Independent State of Croatia and Hungary. However, the exchange was made impossible from the beginning because of the annexation of Medjimurje to Hungary. Both countries were trying to improve the position of the Hungarians in the NDH and of the Croats in Hungarian territory, especially in Medjimurje and Bačka. In December 1941, the first requests were made for emigration of the Hungarians from north-east Bosnia because of the war danger and partisan attacks. This was accomplished in the spring of 1942. As a counter-favor the Hungarians allowed the Croats, who were leaving or were deported from the Hungarian territory, to take their personal belongings with them. Hungarian citizens in the Croatian territory, who were primary rural, were trying to be neutral and were willing to cooperate with the People's Liberation Army and the Partisan Detachments/Yugoslav Army by providing food supplies. However, as Hungarians were „,citizens of the enemy country“, the partisans usually required mobilization of men or forced them to move out without any belongings. The communist government of Yugoslavia was more flexible towards the Hungarians than towards the Germans, especially when it came to repatriation, because the Germans were treated as more responsible in the Second World War. Milder treatment of the Hungarians served also as the Yugoslav contribution, boosted by the USSR, to the establishment of the communist Hungary. It was also important that the Hungarians, unlike the Germans, were mostly smallholders or poor. The Hungarians who stayed in Croatia shared the destiny of the Croats and others in later migrations. In spite of the non-familiar language, the Hungarians have partly assimilated to the majority people, which was also caused by mixed marriages. 